\title{
In vitro Study on the Effect of Some Plant Extracts, Cow urine, Cow dung, Cow milk and Honey against Colletotrichum capsici
}

\author{
Roseline Salam, Ph. Sobita Devi, Bireswar Sinha*, Rahee Bui, \\ K. Dinesh and W. Tampakleima Chanu
}
Department of Plant Pathology, College of agriculture, Central Agricultural University, Imphal-795004, India
*Corresponding author

\begin{tabular}{|c|c|}
\hline & A B S T R A C T \\
\hline $\begin{array}{l}\text { K e y w o r d s } \\
\text { Chilli, Cow urine, } \\
\text { Cow dung, Cow } \\
\text { milk, honey, plant } \\
\text { extracts }\end{array}$ & \multirow{3}{*}{$\begin{array}{l}\text { Anthracnose of chilli caused by Colletotrichum capsici is a widespread problem limiting } \\
\text { the profitable cultivation of chilli in Manipur. An experiment on antifungal efficacy of four } \\
\text { plant extracts viz., Garlic (Allium sativum), Neem (Azadirachta indica), Citronella } \\
\text { (Cymbopogon spp), Ginger (Zingiber officinale) and three Cow urine, Cow dung, Cow } \\
\text { milk viz., Cow urine, Cow dung, Cow milk and honey was done through poisoned food } \\
\text { technique by setting three concentrations in in vitro conditions against C. capsici. The } \\
\text { results revealed that among the plant extracts, garlic had shown } 70.19 \text { per cent inhibition at } \\
5 \text { per cent concentration and among the Cow urine, Cow dung, Cow milk and honey, cow } \\
\text { milk had shown } 69.80 \text { per cent inhibition at } 15 \text { per cent concentration. Present study } \\
\text { suggests that Garlic and cow milk could be tried for the eco-friendly management of the } \\
\text { disease. Citronella extract and cow dung found to be less effective. }\end{array}$} \\
\hline Article Info & \\
\hline $\begin{array}{l}\text { Accepted: } \\
\text { 20 May } 2018 \\
\text { Available Online: } \\
\text { 10 June } 2018\end{array}$ & \\
\hline
\end{tabular}

\section{Introduction}

Chilli (Capsicum annuum L.) belongs to the Solanaceae family and is considered valuable cash crop around the world and also in Manipur. India ranks first among the chilli growing countries in the world. India is largest producer with 36\% share in global production (Sahitya et al., 2014). The chilli suffers from various diseases and chilli anthracnose is one of the most important among them. It is the most important disease of chilli in tropics and subtropics worldwide. The disease drastically reduces the yield, deteriorates the fruit quality, and hence results in low returns to farmers. In severe cases, the crop loss may exceed 50\%.
Species of the genus Colletotrichum such as C. capsici, C. gloeosporioides, C. acutatum etc. have been identified as pathogens causing chilli anthracnose. Out of these, C. capsiciis the major pathogen causing anthracnose disease (Gomathi and Kannabiran, 2000; Kaur et al., 2006; Susheela, 2012).

Many fungicides such as mancozeb, captan, bavistin, thiram, copper oxychloride, cosan, benlate and ziram are employed in order to control anthracnose disease. The resistance to these fungicides has been noticed in most fungal pathogens including $C$. capsici. Moreover, the residues of these fungicides remain in the harvested produce. Therefore, 
search for alternative disease control strategies are of immense interest. Natural products are promising in terms of their low cost, potential efficacy as well as no or negligible side effects. Plants and their derivatives have been extensively studied for the control of phytopathogenic fungi. Several studies have been carried out on inhibitory potential of many botanical extracts against phytopathogenic fungi including species of Colletotrichum (Kumaran et al., 2003; Rahman et al., 2011; Bajpai and Kang, 2012; Ajith et al., 2012). Hence, the present study was carried out to study the antifungal activity of some plant extracts, Cow urine, Cow dung, Cow milk and honey against $C$. capsici under in vitro.

\section{Materials and Methods}

\section{Poisoned food technique}

Four locally available botanicals namelyGarlic (Allium sativum), Neem (Azadirachta indica), Citronella (Cymbopogon sp.), Ginger (Zingiber officinale) and also cow urine, cow dung, cow milk and honey were evaluated for their efficacy on the growth of the fungus at three concentrations in vitro. Different plant parts were used for the inhibitory effect against Colletotrichum capsici namely Garlic clove, Neem leaves, Citronella leaves and Ginger rhizomes.

\section{Preparation of plant extraction}

The plant parts were collected, washed in running tap water, surface sterilized with $1 \%$ sodium hypochloride and then with sterile distilled water. These were air dried over a blotting paper. The air dried plant parts were crushed separately in sterilized mortar and pestle with sterile distilled water at ratio 1:1 (w/v). These extracts were filtered through 2 fold muslin cloth and filtrate was centrifuged at $1500 \mathrm{rpm}$ for 15 minutes and the supernatants were collected. These extracts thus prepared were considered as $100 \%$ concentration. Three concentrations were taken for each treatment. For the plant extracts, different concentrations taken were $1.25,2.5$ and $5 \%$ and for cow's product and honey concentrations taken were 5, 10 and $15 \%$.Required quantity of each treatment was added to the sterilized melted PDA medium in the conical flask under aseptic condition and were shaken for well mixing of the two. Each mixture was then poured into the sterilized petriplate under aseptic condition and allowed to solidify. Medium without any treatment and natural product served as control.

After solidification, each plate was inoculated with $5 \mathrm{~mm}$ diameter mycelium disc cut from the periphery of actively grown culture on PDA. The plates were then incubated at $25 \pm 1^{0} \mathrm{C}$ in inverted position. Observations on the fungal growth were taken till the control plates were fully covered by the test fungus. Each treatment was replicated 3 times with three plates in each replication. Per cent inhibition (PI) on growth was calculated by following the method described by Vincent (1927) as given below:

$\mathrm{PI}=\frac{(\mathrm{C}-\mathrm{T})}{\mathrm{C}} \times 100$

Where,

$\mathrm{C}=$ linear growth of the fungus in control

$\mathrm{T}=$ linear growth of the fungus in treatment

\section{Results and Discussion}

\section{Effect of plant extracts on the growth of C.capsici in vitro}

Four botanicals namely Garlic, Neem, Citronella and Ginger were tried at three different concentrations viz., $1.25 \%, 2.5 \%$ and $5 \%$ against $C$. capsici in vitro and the results are presented in table 1 and figure 1 and 3 . 
Table.1 Effect of plant extracts at different concentrations on the growth of C.capsici

\begin{tabular}{|c|c|c|c|c|}
\hline Treatment & $\begin{array}{c}\text { Plant part } \\
\text { used }\end{array}$ & $\begin{array}{c}\text { Concentration } \\
(\%)\end{array}$ & $\begin{array}{l}\text { Colony diameter } \\
\qquad \text { (in cm)* }\end{array}$ & $\begin{array}{l}\text { Inhibition over } \\
\text { control }(\%) *\end{array}$ \\
\hline \multirow[t]{3}{*}{ Garlic } & \multirow[t]{3}{*}{ bulb } & 1.25 & 4.93 & 41.95 \\
\hline & & 2.5 & 4.80 & 43.52 \\
\hline & & 5 & 2.53 & 70.19 \\
\hline \multirow[t]{3}{*}{ Neem } & \multirow[t]{3}{*}{ leaves } & 1.25 & 5.16 & 39.21 \\
\hline & & 2.5 & 4.66 & 45.09 \\
\hline & & 5 & 4.50 & 47.05 \\
\hline \multirow{3}{*}{ Citronella } & \multirow[t]{3}{*}{ leaves } & 1.25 & 6.93 & 18.42 \\
\hline & & 2.5 & 6.66 & 21.56 \\
\hline & & 5 & 6.10 & 28.23 \\
\hline \multirow{3}{*}{ Ginger } & \multirow[t]{3}{*}{ rhizome } & 1.25 & 6.00 & 29.40 \\
\hline & & 2.5 & 5.60 & 34.11 \\
\hline & & 5 & 5.30 & 37.64 \\
\hline \multicolumn{3}{|c|}{ Control (untreated) } & 8.5 & 0.00 \\
\hline $\operatorname{SE}(d)$ & & & & 4.58 \\
\hline $\mathrm{CD}_{(0.05)}$ & & & & 9.47 \\
\hline
\end{tabular}

*Mean of three replications

Table.2 Effect of Cow urine, Cow dung, Cow milk and honey at different concentrations on the growth of $C$. capsici

\begin{tabular}{|c|c|c|c|}
\hline Treatment & $\begin{array}{c}\text { Concentration } \\
(\%)\end{array}$ & $\begin{array}{c}\text { Colony } \\
\text { diameter (in } \\
\text { cm)* }\end{array}$ & $\begin{array}{c}\text { Inhibition over } \\
\text { control }(\%) *\end{array}$ \\
\hline Cow urine & 5 & 3.40 & 59.99 \\
\hline & 10 & 3.20 & 62.34 \\
\hline Cow dung & 15 & 3.04 & 64.30 \\
\hline & 5 & 7.70 & 9.40 \\
\hline & 10 & 7.60 & 10.58 \\
\hline & 15 & 7.56 & 10.97 \\
\hline & 5 & 4.33 & 49.01 \\
\hline Cow milk & 10 & 2.86 & 66.26 \\
\hline & 15 & 2.56 & 69.80 \\
\hline Honey & 5 & 4.43 & 47.83 \\
\hline Control (untreated) & 4.23 & 50.19 \\
\hline SE(d) & 10 & 4.16 & 50.97 \\
\hline CD(0.05) & & 8.5 & 0.00 \\
\hline
\end{tabular}

*Mean of three replications 
Fig.1 In vitro efficacy of plant extracts on the growth of C. capsici

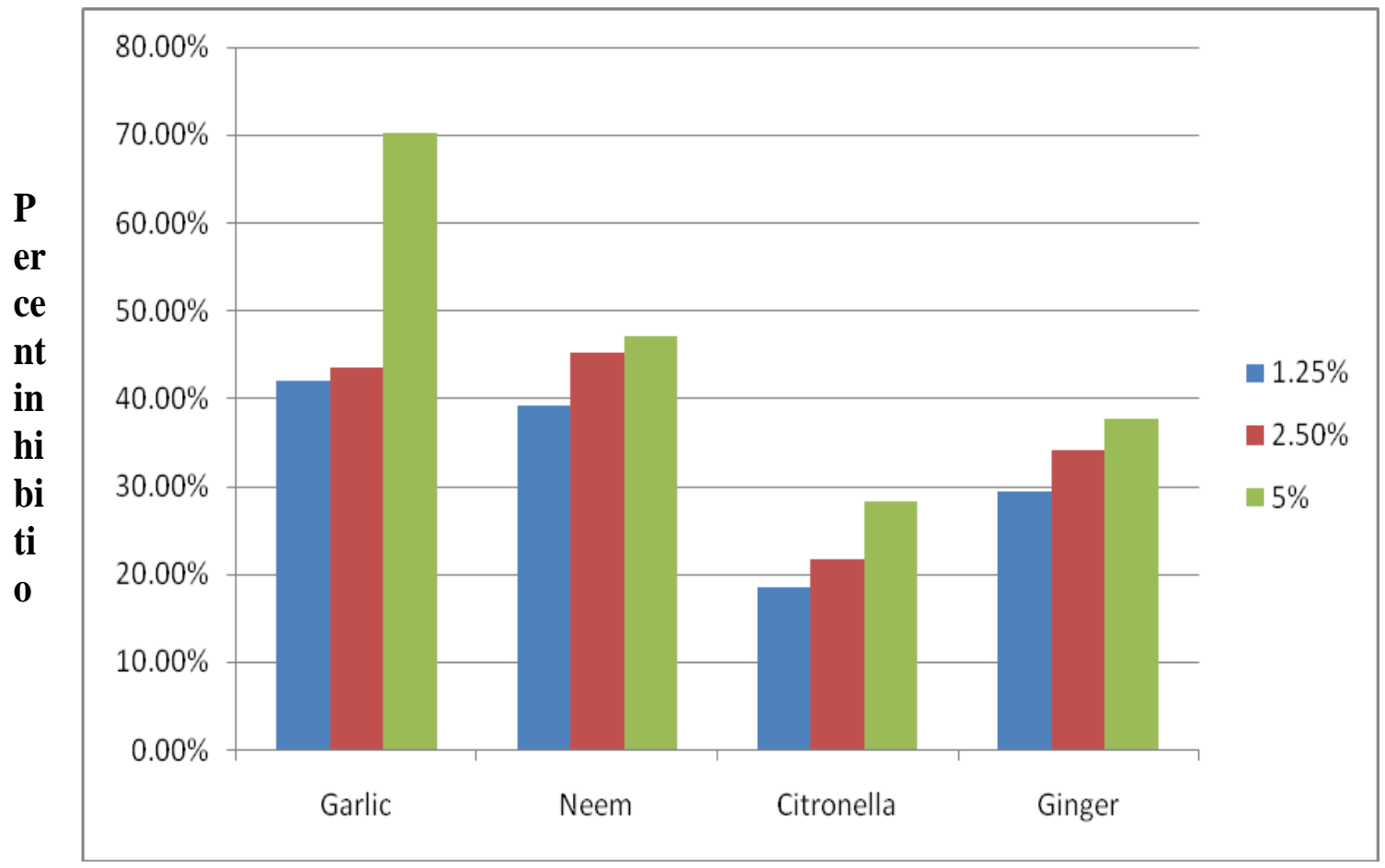

Fig.2 In vitro efficacy of Cow urine, Cow dung, Cow milk on the growth of $C$. capsici at three different concentrations

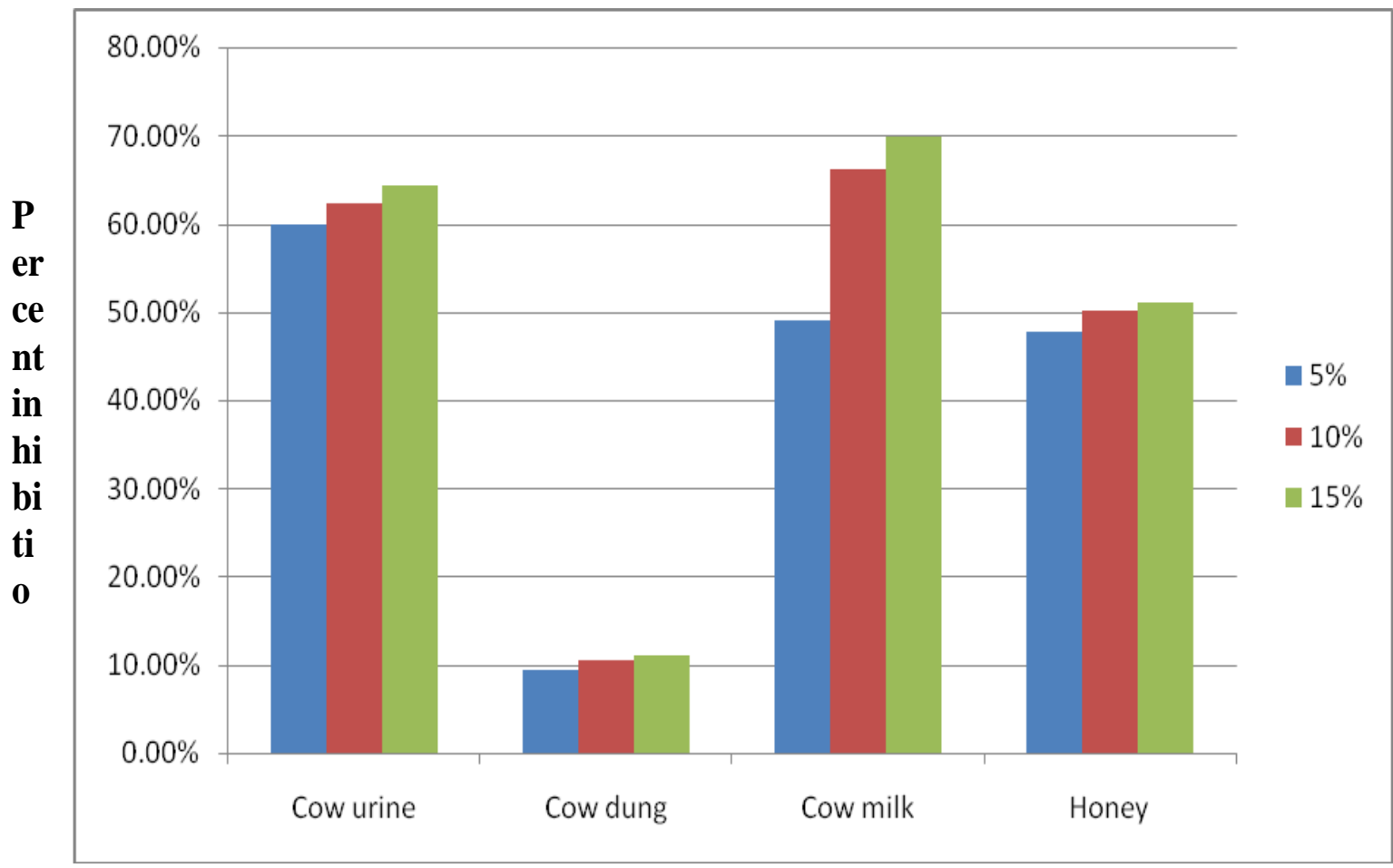


Fig.3 Effect of Garlic, neem, citronella and ginger extracts on growth of $C$. capsiciat three concentrations
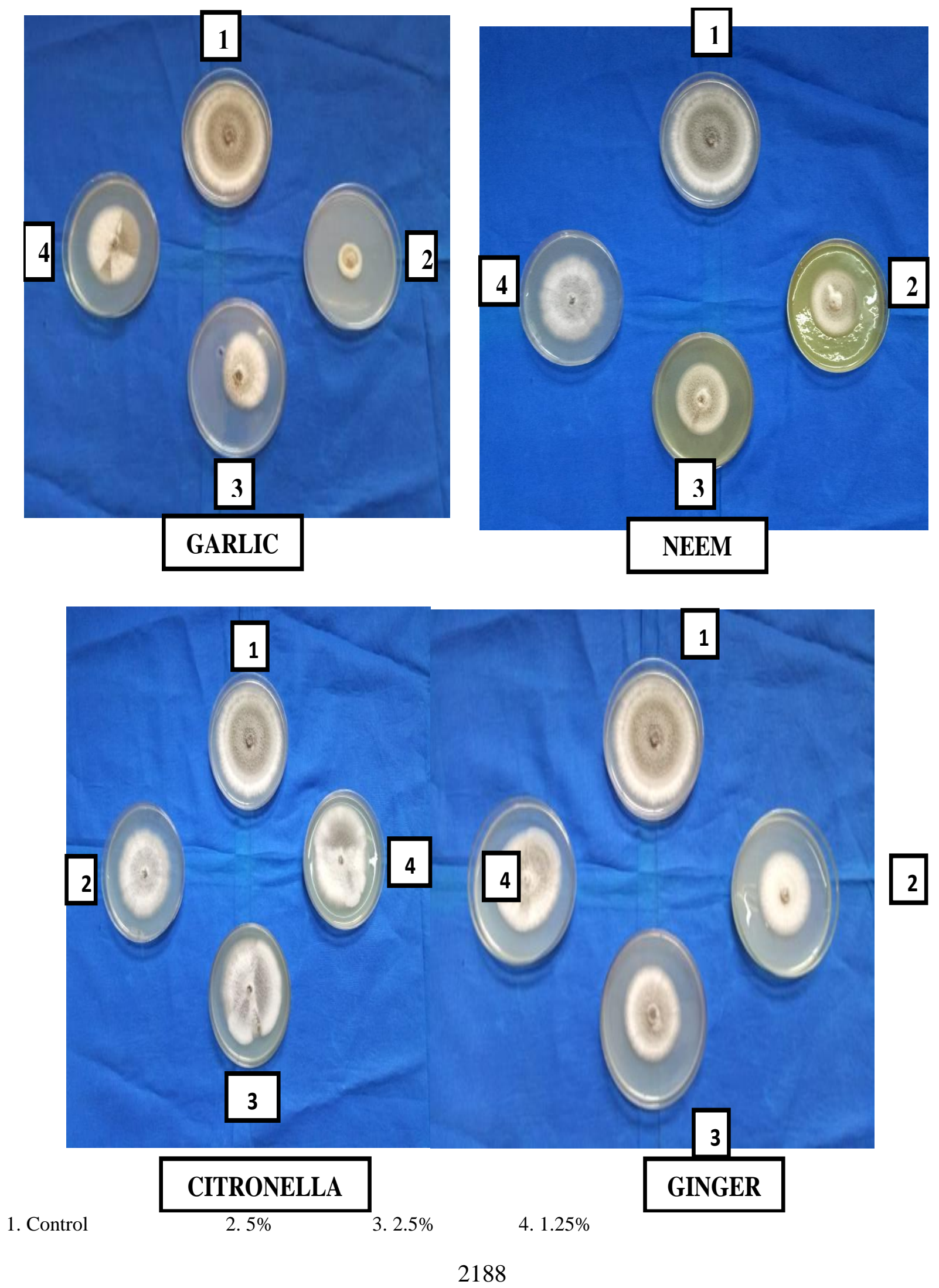
Fig.4 Effect of Cow urine, cow milk, cow dung and honey on growth of $C$. capsici at three concentrations
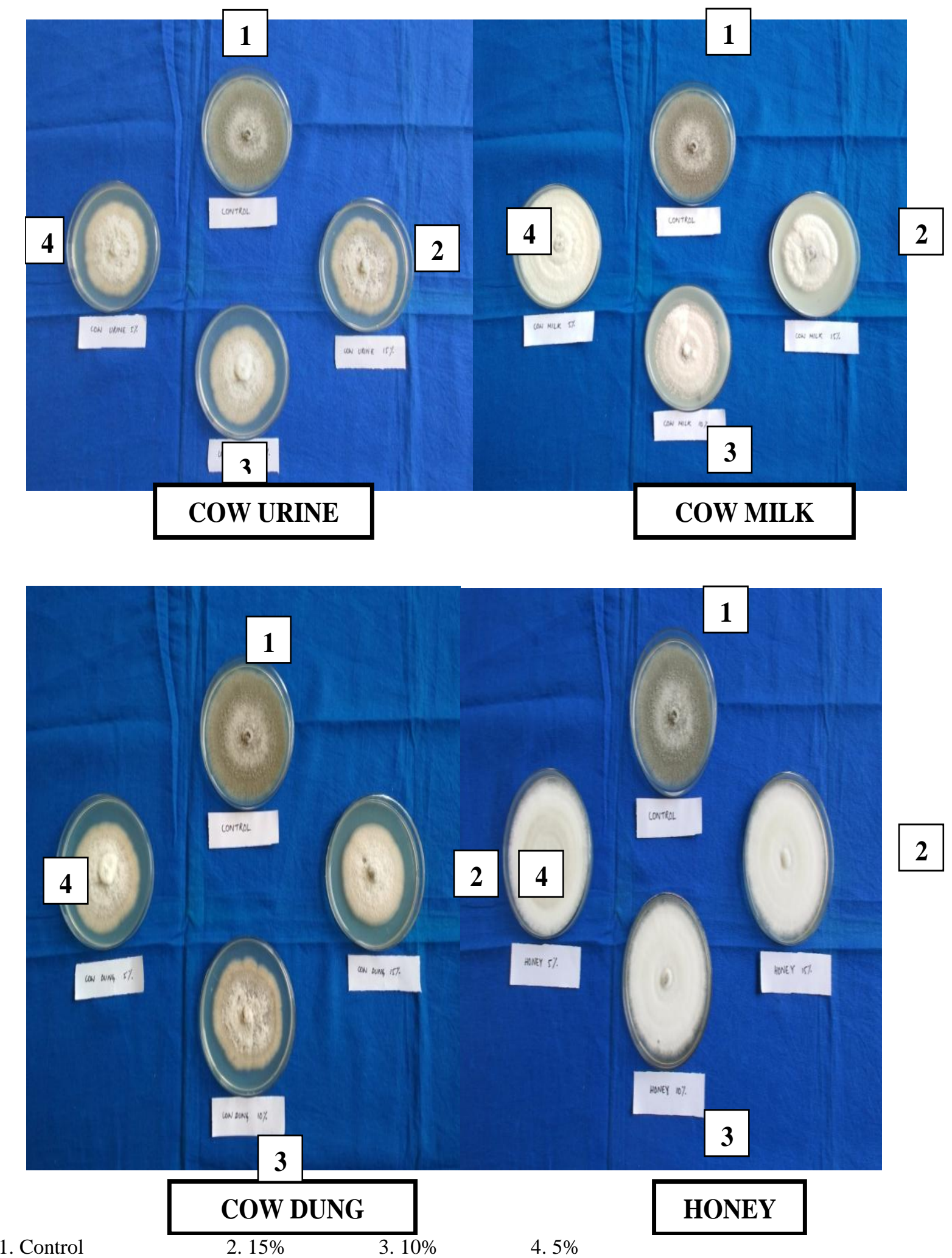
Effect of Cow urine, Cow dung, Cow milk and honey on the growth of C.capsici in vitro

The effect of three Cow urine, Cow dung, Cow milk namely cow urine, cow dung, cow milk and honey were studied in vitro at three concentrations ofviz., 5, 10, and $15 \%$ against C. capsici and the results are presented in table 2 and figure 2 and 4 . The table shows that maximum per cent inhibition of the fungal growth was observed at $15 \%$ cow milk $(69.8 \%)$ followed by $10 \%$ cow milk (66.26\%), 15\% cow urine $(64.30 \%), 5 \%$ cow urine $(59.99 \%), 5 \%$ cow milk (49.01\%), $15 \%$ honey $(50.97 \%), 10 \%$ honey $(50.19 \%), 5 \%$ honey (47.83\%), 15\% cow dung (10.97\%), $10 \%$ cow dung $(10.58 \%)$ and least inhibition was observed at 5\% cow dung with $9.40 \%$. Table also indicated that among the different treatments, cow milk and cow urine were found very effective in inhibiting the growth of the fungus in all the three concentrations tried. Less effectiveness was observed in cow dung treatment. Present findings are in support of the findings of Rahman et al., (2005), Ushakiran et al., (2006), Pardhi and Raut (2011). Rahman et al., (2005) also reported Garlic extracts to be the best for controlling pre- dominant fungi of chilli followed by Neem and Ginger. Kambar et al., (2013) reported the inhibitory effect of cow urine against $C$. capsici under the in vitro study. Ushakiran et al., (2006) also reported high inhibitory effect of the Garlic extract on the growth of the fungi causing fruit rot of chilli. Pardhi and Raut (2011) reported that among the six phytoextracts against C. capsici, Azadirachta indica at 5 and $10 \%$ was found effective for maximum inhibition against five isolates of $C$. capsici.

The differences in the performance of the plant extract and the variation in their effectiveness against the pathogen may be due to differences in their antifungal properties present. Kurucheve et al., 1997; Shetty et al., 1989) mentioned that the variation in antifungal potential of plant extracts may be due to qualitative and quantitative differences in antifungal principles. The high growth inhibition of the pathogen may be observed due to the presence of high quantity of active antifungal compounds like tannins, flavonoids, glycosides and alkaloids (Harborne, 1984).

\section{References}

Ajith, P.S., Lakshmesha, K.K., Murthy, M.S. and Lakshmidevi, N. (2012). Botanicals for control of anthracnose of bell peppers. J. Pl. Protection Sci., 4(1): 1319.

Bajpai, V.K., Kang, S.C. (2012). In vitro and in vivo inhibition of plant pathogenic fungi by essential oil and extracts of Magnolia liliflora Desr. J. Agricultural Sci. Technol., 14: 845-856.

Gomathi, V., Kannabiran, B. (2000). Inhibitory effects of leaf extracts of some plants on the anthracnose fungi infecting Capsicum annum. Indian Phytopathol., 53(3): 305-308.

Kambar, Y., Vivek, M.N., Manasa, M., Kekuda, P.T.R. and Nawaz, N.A.S. (2013). Inhibitory effect of cow urine against Colletotrichum capsici isolated from anthracnose of chilli (Capsicum annuum L.). Sci. Technol. Arts Res. J., 2(4): 91-93.

Kaur, M., Sharma, O.P., Sharma, P.N. (2006). In vitro effect of Trichoderma species on Colletotrichum capisci causing fruit rot of chilli (Capsicum annuum L.). Indian Phytopathol., 59(2): 243-245.

Kumaran, R.S., Gomathi, V., Kannabiran, B. (2003). Fungitoxic effects of root extracts of certain plant species on Colletotrichum capsici causing anthracnose in Capsicum annuum. Indian Phytopathol., 56(1): 114-116. 
Kurucheve, V., Gerard, E.J. and Jayaraj, J. (1997). Screening of higher plants for fungitoxicity against Rhizoctonia solaniin vitro. Indian J. Phytopathol., 50(2): 235-241.

Mukherjee, A., Khandker, S., Islam, M.R., Shahid, S.B. (2011). Efficacy of some plant extracts on the mycelial growth of Colletotrichum gloeosporioides. J. Bangladesh Agric. Uni., 9(1): 43-47.

Pardhi, S. and Raut. (2011). Disease reaction in chilli cultivars against isolates of Colletotrichum capsici. J. Pl. Dis. Sci., 6: 198-199.

Rahman, D.M.M., Khan, A.A. and Mian, I.H. (2005). Control of seed borne fungi of chilli by seed treatment with fungicides and botanicals. Bangladesh $\mathrm{J} . \quad \mathrm{Pl}$. Pathol., 21(2): 63-66.

Sahitya, L., Deepthi, R., Kasim, D., Suneetha, P. and Krishna. (2014). Anthracnose a prevalent disease in capsicum. Res. J. Pharm. Boil. Chem. Sci., 5(3): 15831604.

Shetty, S. R., Prakash, H. S. andShetty, H.S. (1989). Efficacy of certain plant extracts against seedborne infection of Trichoconiella padwickii in paddy (Oryza sativa). Can. J. Bot., 67: 19561959.

Susheela, K. (2012). Evaluation of screening methods for anthracnose disease in chilli. Pest Management Hort. Ecosystems, 18(2): 188-193.

Ushakiran. L., Chhetry. G.K. N. and Singh. N.I. (2006). Fruit rot diseases of chilli and their management in agro- climatic conditions of Manipur. J. Mycopathol. 44(2): 257-262.

Vincent J.M. (1927). Distortion of fungal hyphae in presence of certain inhibitors, Nature, 159: 850.

\section{How to cite this article:}

Roseline Salam, Ph. Sobita Devi, Bireswar Sinha, Rahee Bui, K. Dinesh and Tampakleima Chanu W. 2018. In vitro Study on the Effect of Some Plant Extracts, Cow urine, Cow dung, Cow milk and Honey against Colletotrichum capsici. Int.J.Curr.Microbiol.App.Sci. 7(06): 2184-2191. doi: https://doi.org/10.20546/ijcmas.2018.706.259 